\title{
23. METAL-RICH BASAL SEDIMENTS FROM NORTHEASTERN PACIFIC DEEP SEA DRILLING PROJECT SITES1
}

\author{
Margaret Leinen, Graduate School of Oceanography, University of Rhode Island, Kingston, Rhode Island
}

\begin{abstract}
Sediments from immediately above basalt basement and from between sections of basalt recovered from Deep Sea Drilling Project Legs 5 and 63 were analyzed by atomic absorption spectroscopy for $\mathrm{Mg}, \mathrm{Al}, \mathrm{Si}, \mathrm{Ca}, \mathrm{Mn}, \mathrm{Fe}, \mathrm{Co}, \mathrm{Ni}$, $\mathrm{Cu}, \mathrm{Zn}$, and $\mathrm{Ba}$. All of these sediments showed enrichment in $\mathrm{Fe}$ and $\mathrm{Mn}$ over values typical of detritus supplied to the northeastern Pacific Ocean. X-ray diffractometry and differential chemical leaching indicate that up to $50 \%$ of the sediment, by weight, is in amorphous phases and that these phases are rich in $\mathrm{Mn}, \mathrm{Co}, \mathrm{Cu}, \mathrm{Ni}$, and $\mathrm{Zn}$. Multivariate statistical analysis and normative partitioning of the chemical data indicate that much of the excess $\mathrm{Fe}$ and other transition elements in the sediment originate from hydrothermal sources.
\end{abstract}

\section{INTRODUCTION}

Sediments deposited above basalt basement in the Pacific Ocean are typically reddish brown, fine-grained, and enriched in $\mathrm{Fe}, \mathrm{Mn}$, and other transition elements (von der Borch and Rex, 1970; Cronan, 1973, 1976). Recent studies of actively spreading ridges in the Pacific indicate that such sediments form from the reaction of hydrothermal solutions with oxygenated bottom water (Edmond et al., 1977; Edmond and Gordon, 1979; Corliss et al., 1978, 1979; Spiess, et al., 1980). Whereas the recently formed sediments have been the subject of intensive chemical and mineralogical study, less effort has been made to compare them with metal-rich sediments found as basal sediment above basalt in Deep Sea Drilling Project sites.

Drilling at Sites $469,470,471$, and 472 on DSDP Leg 63 recovered basalt or diabase basement and sediments immediately overlying sediments. At two of the sites, 469 and 471 , the recovered sediment is fine-grained, reddish brown, and similar in appearance to that found near basalt basement at other eastern Pacific drill sites. Most of the basal sediment from Leg 63 sites contains appreciable quantities of calcareous and siliceous biogenic material, however. At one site, 471, we found similar reddish brown sediment in association with an assemblage of sulfides, cherts, and highly altered diabase rocks. Backtracking this site to its position at the time of crustal generation about $15 \mathrm{Ma}$ (Bukry, this volume) indicates that it formed at nearly the same position along the East Pacific Rise as the active hydrothermal vents recently discovered near $21^{\circ} \mathrm{N}$ on the East Pacific Rise, which are also associated with sulfide mineral (Spiess et al., 1980).

The composition of the basal sediments from Leg 63 was analyzed to determine whether they showed evidence of enrichment in elements known to be contributed to seawater from hydrothermal solutions (e.g.,

${ }^{1}$ Initial Reports of the Deep Sea Drilling Project, Volume 63.
$\mathrm{Fe}, \mathrm{Mn}$ ) or in hydrothermal phases like amorphous iron oxides and hydroxides or iron-rich smectites. At several other DSDP holes drilled nearby in the northeast Pacific, we encountered metal-rich sediment just above basalt basement (von der Borch and Rex, 1970; Dymond et al., 1973). Holes drilled by Leg 5 (at Sites 32, 36, 37, 38, and 39) were among the first to yield such material as a basal layer. Samples from these sites were also analyzed in order to compare the Leg 63 basal sediments with those deposited near the same section of the East Pacific Rise when it was further from the influences of terrigenous and biogenic sedimentation (see Fig. 1).

\section{METHODS}

Samples for analysis were chosen from sediments as close as possible to the sediment/basalt contact. Additional samples of sediment interlayered with basalt were analyzed from Sites 469,471 , and 472 (Table 1). Individual samples were freeze-dried and homogenized by dry splitting. The carbonate content of each sample was determined in duplicate gasometrically by dissolving 1-gram samples with $50 \% \mathrm{HCl}$ in a calibrated pressure bomb. The accuracy of this technique is about \pm 2 wt. $\%$ calcite. The precision of duplicate determinations was better than \pm 1 wt. $\%$ calcite. In order to correct chemical analysis for dilution by sea salt from interstitial waters, the salt content of the sediment was determined. Sea-salt contents were calculated from the $\mathrm{Cl}$ concentration of the sediment determined by this method is $\pm 0.25 \mathrm{wt}$. $\%$ sea salt. Mineralogy of selected samples was determined by X-ray diffraction analysis of oriented aggregates using the preparation method and X-ray techniques described in Heath and Pisias (1979). The bulk density of the sediment was determined from shipboard measurements (GRAPE) and from on-shore gravimetric analyses provided by DSDP.

The freeze-dried samples were prepared for chemical analysis by a procedure modified from Bernas (1968), which is described by Dymond et al., 1976. The samples were dissolved in HF and aqua regia in Teflon-lined pressure bombs and neutralized with boric acid. The samples were analyzed for $\mathrm{Mg}, \mathrm{Al}, \mathrm{Si}, \mathrm{Ca}, \mathrm{Mn}, \mathrm{Fe}, \mathrm{Cu}, \mathrm{Zn}$, and $\mathrm{Ba}$, by flame atomic absorption spectroscopy and for $\mathrm{Co}$ and $\mathrm{Ni}$ by flameless atomic absorption spectroscopy. The precision of duplicate determinations averaged $\pm 2 \%$ of measured value for $\mathrm{Mg}$ and $\mathrm{Mn}$, $\pm 4 \%$ of measured value for $\mathrm{Al}$ and $\mathrm{Fe}, \pm 8 \%$ of measured value for $\mathrm{Si}, \mathrm{Cu}, \mathrm{Ni}$, and $\mathrm{Zn}$, and $\pm 15 \%$ of measured value for $\mathrm{Co}$ and $\mathrm{Ba}$. Comparison of these analyses with U.S. Geological Survey Rock Standards AGV-1 and GSP-1 indicated no systematic error.

Much of the material in freshly precipitated hydrothermal sediment is composed of poorly crystallized, X-ray amorphous iron and manganese oxides and hydroxides (Dymond et al., 1973). Landa and 


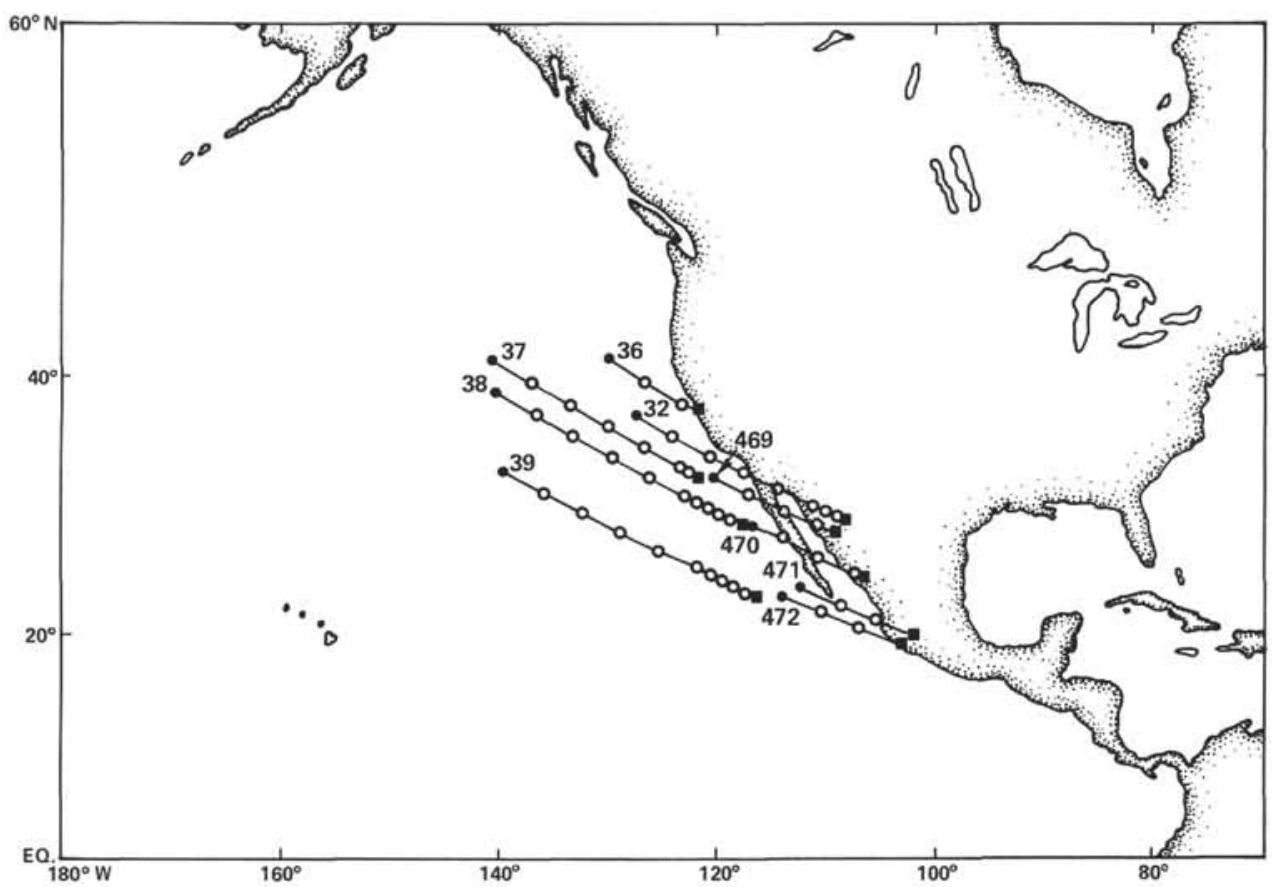

Figure 1. Backtrack paths of DSDP sites in the northeastern Pacific. (Present positions of sites are indicated with solid dots. Positions of sites at the time of formation and of hydrothermal sediment deposition are indicated with squares. Open dots show positions of sites at 5-m.y. intervals. Plate rotation parameters are discussed in text.)

Table 1. Legs 5 and 63 hole locations, sample intervals, sample descriptions, and basement age.

\begin{tabular}{|c|c|c|c|c|c|c|}
\hline $\begin{array}{l}\text { Hole or } \\
\text { Site }\end{array}$ & Location & Core & Section & Interval $(\mathrm{cm})$ & Age (m.y.) & Sample Description \\
\hline 32 & $37^{\circ} 7^{\prime} \mathrm{N} 127^{\circ} 33^{\prime} \mathrm{W}$ & 12 & 6 & $97-99$ & $34-38$ & $\begin{array}{l}\text { Nannofossil "red clay" with some dolomite } \\
\text { rhombs immediately above basalt basement }\end{array}$ \\
\hline 36 & $40^{\circ} 59^{\prime} \mathrm{N} 130^{\circ} 7^{\prime} \mathrm{W}$ & 13 & 4 & $126-128$ & $7-11$ & $\begin{array}{l}\text { Light olive gray nannofossil clay immediately } \\
\text { above basalt basement }\end{array}$ \\
\hline 37 & $40^{\circ} 59^{\prime} 140^{\circ} 43^{\prime} \mathrm{W}$ & 4 & 5 & $85-86$ & $20-30$ & $\begin{array}{l}\text { Zeolitic "iron-oxide sediment" immediately } \\
\text { above basalt basement }\end{array}$ \\
\hline 38 & $38^{\circ} 42^{\prime} \mathrm{N} 140^{\circ} 21^{\prime} \mathrm{W}$ & 6 & 6 & $107-109$ & $49-51$ & $\begin{array}{l}\text { Nannofossil ooze and amorphous iron above } \\
\text { inferred basalt basement }\end{array}$ \\
\hline 39 & $32^{\circ} 48^{\prime} \mathrm{N} 139^{\circ} 34^{\prime} \mathrm{W}$ & 2 & 6 & $41-43$ & $50-53$ & $\begin{array}{l}\text { Amorphous iron oxides with foraminifers and } \\
\text { nannofossils immediately above basalt basement }\end{array}$ \\
\hline 469 & $32^{\circ} 37^{\prime} \mathrm{N} 120^{\circ} 33^{\prime} \mathrm{W}$ & 43 & 3 & $74-76$ & $16-18$ & $\begin{array}{l}\text { Reddish brown dolomitic iron-rich clay im- } \\
\text { mediately above basalt basement }\end{array}$ \\
\hline 469 & & 45 & 1 & $86-90$ & & $\begin{array}{l}\text { Reddish brown clayey limestone between sections } \\
\text { of basalt breccia }\end{array}$ \\
\hline $470 \mathrm{~A}$ & $28^{\circ} 55^{\prime} \mathrm{N} 117^{\circ} 31^{\prime} \mathrm{W}$ & 7 & 1 & $53-56$ & $15-17$ & $\begin{array}{l}\text { Pale olive dolomitic claystone immediately above } \\
\text { basalt basement }\end{array}$ \\
\hline $471_{\mathrm{a}}$ & $23^{\circ} 29^{\prime} \mathrm{N} 112^{\circ} 30^{\prime} \mathrm{W}$ & 79 & 1 & $87-94$ & $13-15$ & $\begin{array}{l}\text { Dusky yellowish brown iron-rich clay recovered } \\
\text { from between sulfide-bearing sediment and black } \\
\text { quartzose chert }\end{array}$ \\
\hline $471_{b}$ & & 80 & 1 & 4-8 & & $\begin{array}{l}\text { Light olive gray laminated claystone with lenses } \\
\text { or layers of dark red claystone from between } \\
\text { sections of diabase }\end{array}$ \\
\hline $471_{c}$ & & 82 & 1 & $86-88$ & & $\begin{array}{l}\text { Grayish brown claystone from between sections } \\
\text { of diabase }\end{array}$ \\
\hline $472_{a}$ & $23^{\circ} 0^{\prime} \mathrm{N} 114^{\circ} 0^{\prime} \mathrm{W}$ & 12 & 2 & $54-55$ & $15-17$ & $\begin{array}{l}\text { Iron-oxide-rich dolomitic nannofossil ooze from } \\
\text { core immediately above basalt basement }\end{array}$ \\
\hline $\begin{array}{l}472 \mathrm{~b} \\
472 \mathrm{c}\end{array}$ & & 12 & 4 & 139-141 & & 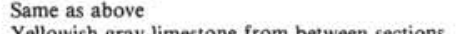 \\
\hline $472 \mathrm{c}$ & & 15 & 1 & $51-57$ & & $\begin{array}{l}\text { Yellowish gray limestone from between sections } \\
\text { of basalt }\end{array}$ \\
\hline
\end{tabular}

Note: Sample descriptions are taken from those listed in the core description section of the site summaries for each of the sites used. Subscript, lower-case letters attached to hole numbers indicate different samples or sections from the holes.

Gast (1973) have shown that amorphous iron phases can be dissolved using an oxalic acid-ammonium oxalate leach. This technique cannot be used on calcareous sediments, however, because the leach solution forms an insoluble precipitate with $\mathrm{Ca}$. Although other reducing acid or complexing solutions that do not form an insoluble precipitate can be used to remove amorphous $\mathrm{Fe}$ (e.g., Chester and Hughes, 1967), these techniques also attack Fe-rich smectite, a common authigenic/diagenetic phase in metal-rich deep-sea sediments. In order to use the oxalic-acid leach technique on these sediments, the samples were first leached with acetic acid buffered to $\mathrm{pH}=4.5$ with sodium acetate to remove calcium carbonate, weakly sorbed species, and salt from the sediment. Then $100-\mathrm{ml}$ aliquots of sodium-acetate buffered acetic acid were added to the samples, and the samples were shaken for one hour. The samples were then filtered to remove the insoluble residue, and the $p \mathrm{H}$ of the leach solution was tested to determine whether all of the calcite had been removed. If the $p \mathrm{H}$ of the leach solution was greater than 5.2 and/or if calcareous debris was visible in the insoluble residue, the residue was leached with an additional ali- 
quot of buffered acetic acid. The acetic-acid leach solution was analyzed for $\mathrm{Fe}, \mathrm{Mn}, \mathrm{Co}, \mathrm{Ni}$, and $\mathrm{Cu}$ by flameless atomic absorption to determine whether any of the amorphous iron-rich material was leached and to monitor the concentration of trace metals associated with the calcium carbonate fraction of the sediment. Mg could not be determined in the leach solution because of contamination from the sodium acetate. Preliminary analyses indicated that the concentrations of $\mathrm{Al}, \mathrm{Si}$, and $\mathrm{Ba}$ were always lower than the detection limit of these elements by flame atomic absorption spectroscopy, and they were not analyzed in subsequent analyses. A quantity equal to $10 \%$ by volume of $1 \mathrm{M}$ ascorbic acid was added to the leachate before analysis to reduce spattering and aerosol formation in the graphite furnace. The precision of duplicate determinations of trace elements in the acetic-acid leachable sediment fraction was about $\pm 10 \%$ of measured value for $\mathrm{Mn}$ and $\mathrm{Fe}$ and about $15 \%$ of measured value for $\mathrm{Co}, \mathrm{Ni}$, and $\mathrm{Cu}$. The carbonate-free residues were washed with deionized water, freeze-dried, and weighed.

The composition of the amorphous and poorly crystalline oxide component of the sediment was determined by leaching the samples with $0.2 \mathrm{M}$ oxalic acid buffered to $\mathrm{pH}=3.0$ with $0.2 \mathrm{M}$ ammonium oxalate (Landa and Gast, 1973). This treatment has been shown to dissolve X-ray amorphous and poorly crystallized iron-rich phases but will not attack well crystallized phases such as goethite (Landa and Gast, 1973) and iron-rich smectite (Heath and Dymond, 1977). The leachate was analyzed by flame atomic absorption for $\mathrm{Mg}, \mathrm{Al}, \mathrm{Si}, \mathrm{Mn}$, $\mathrm{Fe}$, and $\mathrm{Ba}$ and by flameless analyzed by flame atomic absorption for $\mathrm{Co}, \mathrm{Ni}$, and $\mathrm{Cu}$. Because $\mathrm{Ca}$ forms an insoluble precipitate with the leach solution, it was not determined. $\mathrm{Zn}$ could not be determined because of high levels of $\mathrm{Zn}$ contamination from the ammonium oxalate. The precision of duplicate analyses was $\pm 5 \%$ of measured value for $\mathrm{Mg}, \mathrm{Mn}$, and $\mathrm{Fe}$ and $\pm 5 \%$ to $10 \%$ of measured value for $\mathrm{Al}, \mathrm{Si}, \mathrm{Co}, \mathrm{Ni}, \mathrm{Cu}$, and $\mathrm{Ba}$. The accuracy of elemental analyses was determined by replicate leachings of an in-house pelagic clay standard and was of the same magnitude as the precision of duplicate determinations. The total sediment leached from samples was determined by weighing the freeze-dried residue after washing five times in deionized water to remove calcium oxalate and other salts. Previous work with the leach technique in our laboratory has indicated that the analytically determined composition of the residual material matches closely ( $\pm 5 \%$ of measured value) the composition calculated from the difference between analytically determined bulk and leachable concentrations. Therefore, the composition of the residual material not leached by the two treatments was calculated by difference.

\section{PALEOPOSITION OF DSDP SITES}

To reconstruct the position of the DSDP sites along the spreading center at the time of basal sediment deposition, the sites were backtracked along the paths they have followed in response to seafloor spreading. The plate rotation parameters for the plates formed at eastern Pacific spreading centers, the Pacific, Nazca, and Cocos plates, are not well known (Suarez et al., 1979; Hammond and Epp, 1978). Rotation parameters for the Pacific plate have been constrained by the position of the equatorial biogenic sediment maximum (van Andel et al., 1975) and by paleomagnetic inclination data from seamounts in the Emperor chain (Prince, 1978; Suarez et al., 1979). These constraints suggest that the model for Pacific plate rotation used by van Andel et al. (1975) is adequate. No such independent constraints are available for the Cocos and Nazca plates. Rotation parameters used in this study are the presentday rotation poles and rates derived by Minster et al. (1974).

The present positions and the backtracking paths of the sites are indicated in Figure 1 along with their positions at the time their basal sediments were deposited. The plate rotation model results in the rotation of many of the northeast Pacific sites over North America. This is not because of an error in the plate rotation parameters but is the result of convergence between the North American and Pacific plates (Atwater, 1970), which has not been included in the simple model used here because it is even less well known than the other relative plate motions (Atwater, 1970). Because this study is only concerned with sedimentation that occurs at the ridge crest, it is only necessary to obtain a general location of the sites with respect to one another, and errors in the plate rotation parameters will have little effect on any conclusions.

\section{RESULTS}

\section{Sediment Composition}

The chemical composition of the bulk sediment from each of the samples is listed in Table 2. All data have been corrected for dilution by sea salt. Also included in Table 2 are the calcite contents (salt-free) and the salt contents of the sediments. When summed as oxides, the elements analyzed account for about $80 \%$ of the carbonate-free sediment. Many of the phases in authigenic and hydrothermal sediment are hydrous and contain appreciable water that would increase in the percentage of sediment accounted for in the analyses. $\mathrm{K}$ and $\mathrm{P}$, which are known to be concentrated in metalliferous sediments, were not included in the analyses.

The concentrations of $\mathrm{Mn}, \mathrm{Fe}, \mathrm{Co}, \mathrm{Ni}$, and $\mathrm{Cu}$ leached by treatment with buffered acetic acid together with the concentrations of elements dissolved by the ammonium oxalate-oxalic acid leach treatment are given in Table 3. The percentages of the total concentration that were leached by the two treatments are also listed in Table 3 . Little of the $\mathrm{Al}, \mathrm{Si}, \mathrm{Fe}$, and $\mathrm{Ba}$ are leached by the acid treatments. The remaining elements are more highly concentrated in soluble phases with the proportion of the leachable element increasing: $\mathrm{Cu}<\mathrm{Ni}<\mathrm{Mn}<\mathrm{Co}$. Only Mn, Co, and Ni had more than $10 \%$ of their concentration leached by the acetic-acid treatment.

\section{DISCUSSION}

The earliest studies of metal-rich sediments from the crest of the East Pacific Rise and from basal sediments in DSDP sites described them as iron-rich-aluminumpoor (Boström and Peterson, 1969). By even these simple criteria, all of the basalt sediments and sediments interlayered with basalt in the northeastern Pacific DSDP sites are metalliferous. Figure 2 shows the $\mathrm{Fe} / \mathrm{Al}$ ratio in the sediments and includes lines for granite and andesite as reasonable extremes of $\mathrm{Fe} / \mathrm{Al}$ in average detritus for this area.

\section{Interelement Associations}

Studies of metal-rich sediments accumulating at the crest of the East Pacific Rise at present (Dymond et al., 1973; Boström et al., 1973; Boström, 1974; Heath and Dymond, 1977) and in the past (Cronan, 1976; Leinen and Stakes, 1979) have shown that the sediments are often mixed with biogenic sediment and with terrigenous detritus. This is certainly true for Leg 63 sites. 
Table 2. Concentrations of elements in bulk sediment (B), acetic-acid leachable (AL), oxalic-acid leachable (OX), and nonleachable residue (R) fractions and calcium carbonate contents of basal sediments from eastern Pacific DSDP sites.

\begin{tabular}{|c|c|c|c|c|c|c|c|c|c|c|c|c|c|c|}
\hline $\begin{array}{c}\text { Hole or } \\
\text { Site }\end{array}$ & Fraction & $\mathrm{Mg}$ & $\mathrm{Al}$ & $\mathrm{Si}$ & $\mathrm{Ca}$ & $\mathrm{Mn}$ & $\mathrm{Fe}$ & Co & $\mathrm{Ni}$ & $\mathrm{Cu}$ & $\mathrm{Zn}$ & $\mathrm{Ba}$ & $\mathrm{CaCO}_{3}$ & Salt \\
\hline \multirow[t]{4}{*}{32} & B & 2.30 & 6.94 & 23.31 & \multirow[t]{3}{*}{1.42} & 1.69 & 9.70 & 105 & 206 & 354 & \multirow[t]{4}{*}{198} & 7853 & \multirow[t]{4}{*}{2.00} & \multirow[t]{4}{*}{2.08} \\
\hline & $\mathrm{R}$ & 1.92 & 6.89 & 23.25 & & 1.26 & 9.41 & 51 & 175 & 324 & & 7832 & & \\
\hline & $\mathrm{AL}$ & & & & & 435 & 12 & 0 & 2 & 2 & & & & \\
\hline & OX & & 440 & 620 & & 3850 & 2900 & 54 & 29 & 28 & & 21 & & \\
\hline \multirow[t]{4}{*}{36} & B & 3.09 & 7.38 & 24.55 & \multirow{4}{*}{2.94} & 0.57 & 6.22 & 53 & 183 & 179 & \multirow{4}{*}{207} & 8322 & \multirow{4}{*}{2.08} & \multirow{4}{*}{5.83} \\
\hline & $\mathbf{R}$ & 3.06 & 7.29 & 24.50 & & 0.49 & 6.13 & 9 & 129 & 154 & & 8265 & & \\
\hline & $\mathrm{AL}$ & & & & & 450 & 70 & 8 & 44 & 3 & & & & \\
\hline & OX & & 900 & 550 & & 350 & 910 & 36 & 10 & 22 & & 57 & & \\
\hline \multirow[t]{2}{*}{37} & $\begin{array}{l}\mathrm{B} \\
\mathrm{R}\end{array}$ & 2.51 & 3.80 & 16.83 & 0.95 & 4.67 & 19.97 & 99 & 432 & 543 & \multirow[t]{2}{*}{416} & 817 & \multirow[t]{2}{*}{2.14} & \multirow[t]{2}{*}{8.54} \\
\hline & $\begin{array}{l}\mathrm{AL} \\
\mathrm{OX}\end{array}$ & & & & & 225 & 23 & 0 & 9 & 12 & & & & \\
\hline \multirow[t]{2}{*}{38} & $\begin{array}{l}\mathrm{B} \\
\mathrm{R}\end{array}$ & 0.36 & 0.28 & 0.55 & & 1.36 & 3.16 & 37 & 498 & 135 & \multirow[t]{2}{*}{73} & 297 & \multirow[t]{2}{*}{87.13} & \multirow[t]{2}{*}{8.95} \\
\hline & $\begin{array}{l}\mathrm{AL} \\
\mathrm{OX}\end{array}$ & & & & & 70 & 1 & 0 & 13 & 0 & & & & \\
\hline \multirow[t]{2}{*}{39} & $\begin{array}{l}\mathrm{B} \\
\mathrm{R}\end{array}$ & 1.80 & 2.44 & 5.41 & 2.87 & 9.07 & 28.74 & 189 & 745 & 1215 & \multirow[t]{2}{*}{820} & 1963 & \multirow[t]{2}{*}{2.14} & 5.48 \\
\hline & $\begin{array}{l}\mathrm{AL} \\
\mathrm{OX}\end{array}$ & & & & & 198 & 5 & 0 & 1 & 16 & & & & \\
\hline $469 \mathrm{a}$ & B & 6.23 & 1.70 & 13.91 & 12.12 & 0.62 & 6.77 & 12 & 48 & 93 & 68 & 1400 & 1.41 & 0.50 \\
\hline & $\mathrm{R}$ & 6.20 & 1.70 & 13.83 & & 0.22 & 5.89 & 0 & 32 & 71 & & 1310 & & \\
\hline & $\mathrm{AL}$ & & & & & 3730 & 2260 & 0 & 2 & & & & & \\
\hline & OX & 330 & 50 & 830 & & 330 & 6600 & 12 & 13 & 18 & & 90 & & \\
\hline $469 \mathrm{~b}$ & $\begin{array}{l}\mathrm{B} \\
\mathrm{R}\end{array}$ & 2.11 & 1.74 & 27.57 & 8.99 & 0.43 & 5.52 & 12 & 44 & 154 & 97 & 195 & 18.04 & 8.82 \\
\hline & $\begin{array}{l}\mathrm{AL} \\
\mathrm{OX}\end{array}$ & & & & & 4910 & 3 & 8 & 31 & 5 & & & & \\
\hline $470 \mathrm{~A}$ & B & 6.89 & 3.30 & 18.72 & 7.53 & 0.52 & 5.09 & 17 & 101 & 162 & 146 & 7030 & 1.99 & 1.72 \\
\hline & $\mathrm{R}$ & 6.88 & 3.28 & 18.72 & & 0.18 & 5.02 & 0 & 98 & 150 & & 6930 & & \\
\hline & $\mathrm{AL}$ & & & & & 3240 & 10 & 0 & 0 & 0 & & & & \\
\hline & OX & 150 & 210 & 25 & & 152 & 730 & 17 & 3 & 12 & & 110 & & \\
\hline $471_{a}$ & B & 4.75 & 8.03 & 19.61 & 0.88 & 0.62 & 15.01 & 52 & 269 & 118 & 98 & 1140 & 1.97 & 0.72 \\
\hline & $\mathbf{R}$ & 4.74 & 7.96 & 19.52 & & 0.60 & 14.70 & 17 & 266 & 115 & & 1100 & & \\
\hline & AL & & & & & 94 & 320 & 0 & 0 & 1 & & & & \\
\hline & OX & 110 & 710 & 850 & & 107 & 2760 & 36 & 3 & 3 & & 40 & & \\
\hline${ }^{471} \mathrm{~b}_{\mathrm{b}} \mathrm{R}^{\mathrm{a}}$ & B & 3.80 & 3.68 & 24.51 & 0.40 & 0.29 & 9.93 & 35 & 113 & 13 & 74 & 55 & 4.98 & 0.87 \\
\hline $471_{b} G^{a}$ & B & 2.99 & 4.52 & 31.34 & 0.40 & 0.35 & 9.00 & 37 & 117 & 3 & 43 & 70 & 1.18 & 0.87 \\
\hline $472_{a}$ & B & 2.17 & 2.79 & 10.93 & 16.60 & 1.77 & 6.47 & 32 & 180 & 255 & 162 & 5770 & 34.82 & 2.85 \\
\hline & $\mathrm{R}$ & 1.20 & 2.77 & 10.88 & & 0.77 & 5.92 & 3 & 130 & 206 & & 5590 & & \\
\hline & $\mathrm{AL}$ & & & & & 230 & 18 & 0 & 7 & 8 & & & & \\
\hline ' & ox & & 170 & 450 & & 9730 & 5490 & 29 & 42 & 41 & & 180 & & \\
\hline $472_{b}$ & $\begin{array}{l}\mathrm{B} \\
\mathrm{R}\end{array}$ & 1.60 & 0.43 & 2.22 & & 0.29 & 0.77 & 20 & 121 & 40 & 43 & 370 & 85.07 & 3.47 \\
\hline & $\begin{array}{l}\mathrm{AL} \\
\mathrm{OX}\end{array}$ & & & & & 670 & 230 & 0 & 36 & 5 & & & & \\
\hline $472_{c}$ & B & 2.54 & 12.17 & 20.91 & 5.12 & 0.29 & 6.82 & 30 & 169 & 186 & 262 & 7120 & 10.09 & 3.96 \\
\hline & $\mathbf{R}$ & 2.50 & 12.14 & 20.86 & & 0.22 & 6.67 & 0 & 158 & 171 & & 6900 & & \\
\hline & $\mathrm{AL}$ & & & & & 260 & 20 & 0 & 0 & 3 & & & & \\
\hline & OX & 410 & 340 & 510 & & 410 & 1460 & 30 & 10 & 12 & & 220 & & \\
\hline
\end{tabular}

Note: All data are corrected for salt dilution. Subscript, lower-case letters a-c attached to hole numbers indicate different samples from these holes. See Table 1 for a listing of these samples. Concentrations for $\mathrm{Mg}, \mathrm{Al}, \mathrm{Si}, \mathrm{Mn}$, and $\mathrm{Fe}$ in bulk sediment (B) and residual fraction ( $\mathrm{R}$ ) are in wt. \%; concentrations of these elements in the acetic-acid leachable fraction (AL) and the oxalic-acid leachable fraction (OX) are in ppm.

a Sample $471_{b}$ contains both grayish green $(G)$ and reddish brown $(R)$ sediment. The two sediment types are separated and analyzed individually.

Heath and Dymond (1977) and Dymond (in press) have distinguished sediment of hydrothermal origin using interelement associations derived from factor analysis of the bulk sediment composition and from samples of extreme composition.

In order to determine whether the interelement associations described for modern ridge-crest sediments are similar to those in their ancient analogs, the bulk chemical data were subjected to Q-mode factor analysis (Imbrie and van Andel, 1964). In addition, factor analysis was used to quantify relationships between the fractions of elements dissolved by acetic-acid and oxalic-acid leach techniques and the residual element concentrations. This multivariate statistical technique is particularly well suited to geochemical data, because it describes variance in the data set in terms of a few artificial variables that are independent of each other (algebraically orthogonal). Because trace elements are important constituents of hydrothermal sediments, the concentration data for each element in each sediment 
able 3. Percentage of sediment in acetic-acid leachable (L), oxalicacid leachable $(\mathrm{OX})$, and residual-sediment $(\mathrm{R})$ fractions.

\begin{tabular}{|c|c|c|c|c|c|c|c|c|}
\hline \multirow[b]{2}{*}{ lement } & \multirow[b]{2}{*}{ Fraction } & \multicolumn{6}{|c|}{ Hole or Site } & \multirow[b]{2}{*}{$472 \mathrm{t}$} \\
\hline & & 32 & 36 & 469 & $470 \mathrm{~A}$ & 471 & $472 \mathrm{a}$ & \\
\hline \multirow{3}{*}{$\mathrm{Mn}$} & L & 3 & 8 & 60 & 63 & 2 & 9 & \\
\hline & $\mathrm{OX}$ & 23 & 6 & 5 & 3 & 2 & 14 & \\
\hline & $\mathrm{R}$ & 74 & 86 & 35 & 34 & 96 & 77 & \\
\hline \multirow[t]{3}{*}{$\mathrm{Fe}$} & L & $t$ & $\mathrm{t}$ & 3 & $t$ & $t$ & $\mathrm{t}$ & \\
\hline & ox & 3 & 1 & 10 & 1 & 2 & 2 & \\
\hline & $\mathrm{R}$ & 97 & 99 & 87 & 99 & 98 & 99 & 92 \\
\hline \multirow[t]{3}{*}{ Co } & L & 0 & 14 & $t$ & $t$ & 0 & 0 & \\
\hline & OX & 52 & 68 & 100 & 100 & 68 & 100 & 92 \\
\hline & $\mathrm{R}$ & 48 & 18 & 0 & 0 & 32 & 0 & \\
\hline \multirow[t]{3}{*}{$\mathrm{Ni}$} & $\mathrm{L}$ & 1 & 24 & 5 & 0 & $\mathrm{t}$ & 0 & \\
\hline & OX & 14 & 5 & 27 & 3 & 1 & 6 & 2 \\
\hline & $\mathbf{R}$ & 85 & 71 & 68 & 97 & 99 & 94 & 72 \\
\hline \multirow[t]{3}{*}{$\mathrm{Cu}$} & L & 1 & 2 & 3 & $t$ & 1 & 1 & \\
\hline & OX & 8 & 12 & 20 & 7 & 2 & 6 & 1 \\
\hline & $\mathrm{R}$ & 91 & 86 & 77 & 93 & 97 & 93 & \\
\hline \multirow[t]{3}{*}{$\mathrm{Mg}$} & L & & & & & & & \\
\hline & OX & 17 & 1 & 1 & $\mathrm{t}$ & $\mathrm{t}$ & 2 & 45 \\
\hline & $\mathrm{R}^{\mathrm{a}}$ & & & & & & & \\
\hline \multirow[t]{3}{*}{$\mathrm{Al}$} & L & & & & & & & \\
\hline & OX & 1 & 1 & $t$ & 1 & 1 & $t$ & \\
\hline & $\mathrm{R}^{\mathrm{b}}$ & 99 & 99 & 100 & 99 & 99 & 100 & 99 \\
\hline \multirow[t]{3}{*}{$\mathrm{Si}$} & $\mathrm{L}$ & & & & & & & \\
\hline & ox & $t$ & $\mathrm{t}$ & 1 & $\mathrm{t}$ & $\mathrm{t}$ & $t$ & \\
\hline & $\mathrm{R}^{\mathrm{b}}$ & 100 & 100 & 99 & 100 & 100 & 100 & 100 \\
\hline \multirow[t]{3}{*}{$\mathrm{Ba}$} & $\mathrm{L}$ & & & & & & & \\
\hline & OX & $\mathrm{t}$ & 1 & 7 & 2 & 4 & 3 & 3 \\
\hline & $\mathrm{R}^{\mathrm{b}}$ & 100 & 99 & 93 & 98 & 96 & 97 & 97 \\
\hline
\end{tabular}

Note: $\mathrm{t}=$ trace; subscript, lower-case letters attached to Hole 472 indicate different samples or sections from the hole. Table 1 identifies these samples.

a $\mathrm{Mg}$ could not be determined in the acetic acid leach solution due to contamination. Because biogenic calcite generally contains $\mathrm{Mg}$, the residual concentration was not calculated.

b $\mathrm{Al}, \mathrm{Si}$, and $\mathrm{Ba}$ were below the detection limit in the acetic acid leach solution, and their concentrations in the acetic acid leachable sediment fraction have been assumed to be zero in calculating a residual concentration.

fraction (acetic-acid leachable, oxalic-acid leachable, and nonleachable) were normalized to equal means before the factor analysis. This procedure preserves relative intersample relationships for each element but prevents major elements from dominating the statistical analysis.

In order to compare the results of a factor analysis of the DSDP basal sediments with those from a factor analysis of modern East Pacific Rise sediments (Heath and Dymond, in press), only the eight elements used by Heath and Dymond were factored: $\mathrm{A}, \mathrm{Si}, \mathrm{Mn}, \mathrm{Fe}, \mathrm{Cu}$, $\mathrm{Ni}, \mathrm{Zn}$, and $\mathrm{Ba}$. Three factors account for more than $93 \%$ of the variance in the composition of the bulk basal sediment in the northeast Pacific DSDP sites. The importance of each element in each factor is shown in Figure 3. The transition elements $\mathrm{Mn}, \mathrm{Fe}, \mathrm{Ni}, \mathrm{Cu}$, and $\mathrm{Zn}$ are concentrated in Factor 1, an association common in all hydrothermal sediments. Factor 2 is dominated by $\mathrm{Si}$ and is negatively associated with $\mathrm{Ba}$. Factor 3 is dominated by $\mathrm{Al}$ and $\mathrm{Ba}$. When $\mathrm{Mg}, \mathrm{Co}$, and calcite content were added to the data set, four factors were necessary to explain $92 \%$ of the variance. In this second analysis, three factors had compositions similar to those just

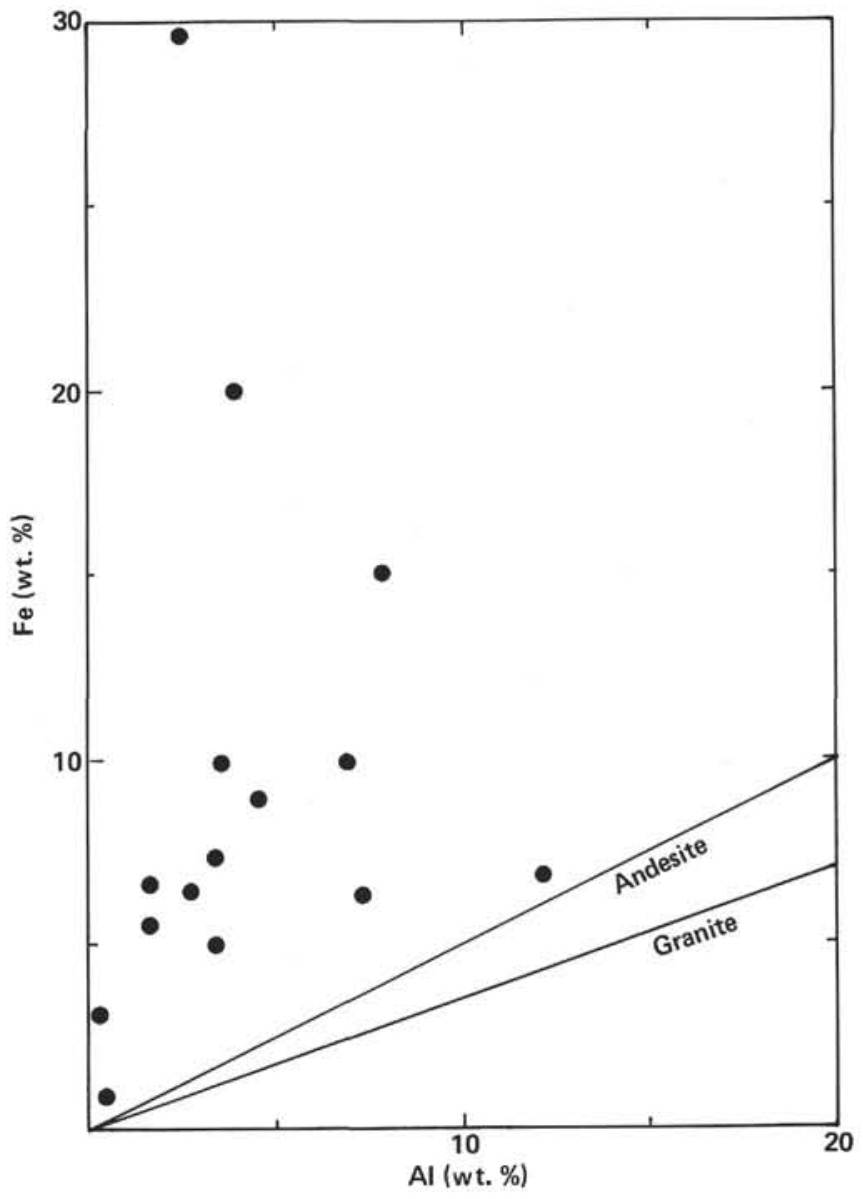

Figure 2. $\mathrm{Fe} / \mathrm{Al}$ ratio of basal sediments from northeastern Pacific DSDP sites. (Lines show $\mathrm{Fe} / \mathrm{Al}$ ratio of andesite and granite.)

described and shown in Figure 3. Mg was strongly concentrated in the silica-rich factor. Co was enriched in the transition-element-dominated factor, and calcium carbonate dominated the new fourth factor. If the original data for the factor analysis are summed to a constant value for each sample, the actual composition of the factors can be recovered in addition to the variance compositions shown in Figure 3 (Pisias and Leinen, 1980). Because the elements, when summed as oxides, account for approximately $80 \%$ of the noncarbonate sediment fraction in all of the samples, it is reasonable to sum the oxides and the carbonate content to $100 \%$ of the sediment. When this is done, compositions can be generated for each of the factors. These are listed in Table 4.

It is clear that the factors are not necessarily single phases. For example, the carbonate-rich factor also contains nearly $20 \% \mathrm{SiO}_{2}$ and about $2 \%$ each of $\mathrm{Mn}$ as $\mathrm{MnO}_{2}$ and $\mathrm{Fe}$ as $\mathrm{Fe}_{2} \mathrm{O}_{3}$. The acetic-acid leach data indicate that the silica and iron are not in or on the calcium carbonate and that less than $2 \%$ of $\mathrm{Mn}$ as $\mathrm{MnO}_{2}$ is associated with the carbonate (see Table 2). The mixture of phases in the factors probably results from the lack of pure end members within the data set. But the compositions of the factors, when considered together with the bulk and leach fraction chemistry and mineralogy, 

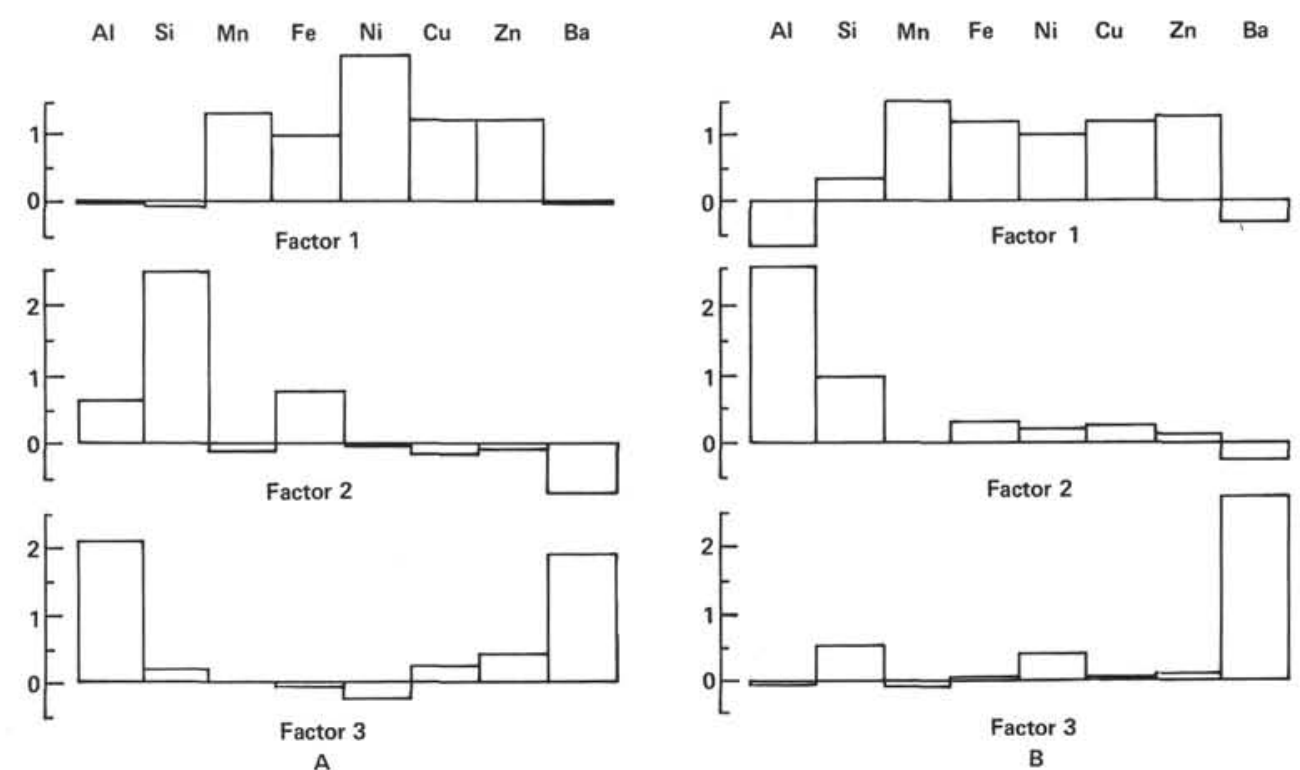

Figure 3. A. Factors generated from chemical data for surface sediments from the East Pacific Rise (Heath and Dymond, in press). B. Factors generated from chemical data for basal sediments from DSDP sites in the northeastern Pacific.

Table 4. Chemical composition of factors from statistical analysis of bulk chemical composition and carbonate content of basal sediments from northeastern Pacific DSDP sites.

\begin{tabular}{lcccc}
\hline & Factor 1 & Factor 2 & Factor 3 & Factor 4 \\
\hline $\mathrm{CaCO}_{3}$ & 0.1 & 6.4 & 11.2 & 72.6 \\
$\mathrm{MgO}$ & 11.5 & 5.3 & 0 & 3.2 \\
$\mathrm{Al}_{2} \mathrm{O}_{3}$ & 3.3 & 7.4 & 38.5 & 0 \\
$\mathrm{SiO}_{2}$ & 2.6 & 67.8 & 34.1 & 19.6 \\
$\mathrm{MnO}_{2}$ & 18.5 & 1.0 & 0.3 & 2.1 \\
$\mathrm{Fe}_{2} \mathrm{O}_{3}$ & 63.4 & 12.1 & 13.2 & 2.3 \\
$\mathrm{CoO}$ & 0.030 & 0.004 & 0.012 & 0.003 \\
$\mathrm{NiO}$ & 0.144 & 0.017 & 0.036 & 0.042 \\
$\mathrm{CuO}$ & 0.184 & 0.007 & 0.051 & 0.021 \\
$\mathrm{ZnO}$ & 0.119 & 0.008 & 0.052 & 0.012 \\
$\mathrm{BaO}$ & 0.088 & 0 & 2.4 & 0.135 \\
\hline
\end{tabular}

Note: Values are in wt. \%.

do give a good idea of the phases and phase compositions that make up the sediment. For example, Factor 2, the silica-rich factor, composes $92 \%$ of the sediment in specimens from Sample 471-80-1, 4-8 cm. These specimens are from a claystone immediately above diabase basement at Site 471 . Smear slides and thin sections of these sediments show clay in a siliceous matrix. Thus this factor is probably a combination of detritus and biogenic silica that has been recrystallized as a siliceous cement. Factor 3 is most enriched $(88 \%)$ in a sample from the basal sediment at Site 36, a red clay with rare, poorly preserved siliceous microfossils and barite. The latter is a phase strongly enriched in sediment characterized by dissolution of siliceous biogenic debris (Dymond, in press). This factor therefore probably represents detritus and phases like barite remaining after the dissolution of biogenic silica.
The factors generated from an analysis that included the acetic-acid and oxalic-acid leach data are similar to those generated from the bulk chemical data but provide insight into the associations of the leachable sediment fractions with the principal sediment types (Fig. 4). Factor 1 accounts for $31 \%$ of the variance in the data and is dominated by nonleachable $\mathrm{Mn}$ and $\mathrm{Co}$ and oxalate-leachable $\mathrm{Mg}, \mathrm{Mn}, \mathrm{Ni}$, and $\mathrm{Fe}$. Element fractions included in this factor suggest hydrothermal influence. The second factor generated using the complete data set is dominated by calcium carbonate and acetic-acidleachable $\mathrm{Mn}$. This factor accounts for $17 \%$ of the variance in the data set and represents calcareous biogenic debris. It is interesting to note that acetic-acidleachable $\mathrm{Mn}$ is also an important constituent of this factor. Although these data do not indicate how the Mn is associated with calcareous debris, Mn coatings and stains are common on calcareous tests; analyses of acidcleaned calcareous shell material show low Mn contents (Boyle, 1979). It is therefore likely that the $\mathrm{Mn}$ is present as a coating on calcareous plankton tests. The third factor explains $16 \%$ of the variance in the data set and is dominated by residual $\mathrm{Al}, \mathrm{Ni}, \mathrm{Mg}, \mathrm{Co}, \mathrm{Fe}$, and $\mathrm{Si}$. The composition of this factor indicates that it represents detritus. Factor 4, which explains $15 \%$ of the variance in the data set, is dominated by acetic-acid leachable Co and $\mathrm{Ni}$ and residual $\mathrm{Si}, \mathrm{Ba}$, and $\mathrm{Zn}$. The latter are commonly associated in siliceous biogenic debris, but the reason for the association of the acetic-acid leachable $\mathrm{Co}$ and $\mathrm{Ni}$ with siliceous sediment is not clear. Both Co and $\mathrm{Ni}$ occur in very small amounts in siliceous biogenic debris (M. Kastner, written comm., 1979). One explanation is suggested by the high factor score for $\mathrm{Ba}$. Because this element is strongly fractionated into the residue remaining after solution of siliceous debris, Fac- 


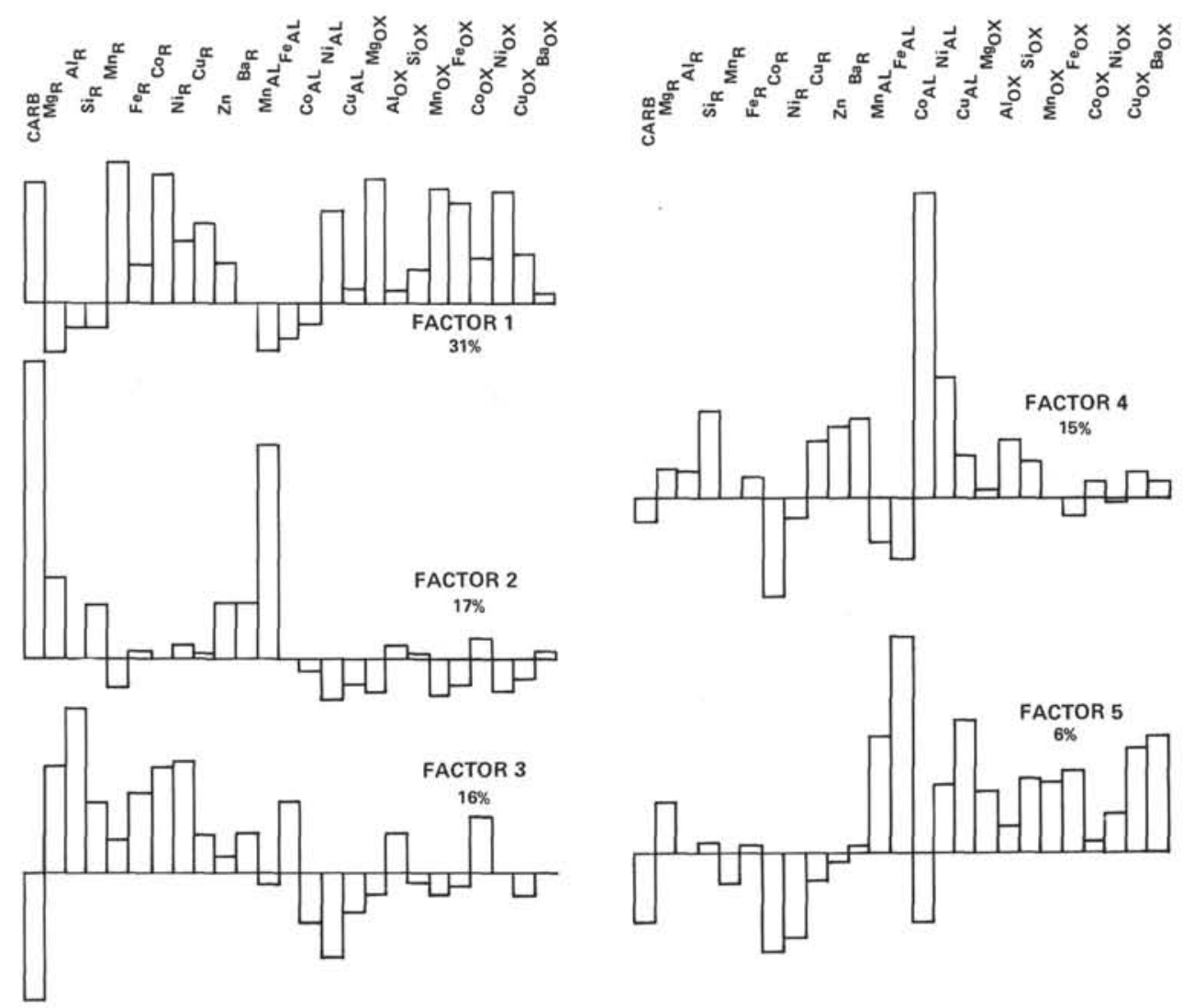

Figure 4. Factors generated from acetic-acid leachable (AL), oxalic-acid leachable $(\mathrm{OX})$, and residual sediment fraction ( $R$ ) chemistry.

tor 4 may represent both siliceous biogenic material and the dissolved residue of the material that would accumulate with other residual and hydrogenous elements such as $\mathrm{Co}$ and $\mathrm{Ni}$. The fifth factor explains $6 \%$ of the variance in the data set and is dominated by acetic-acid leachable $\mathrm{Fe}, \mathrm{Cu}$, and $\mathrm{Mn}$ and by oxalic-acid leachable $\mathrm{Si}, \mathrm{Mn}, \mathrm{Fe}, \mathrm{Cu}$, and $\mathrm{Ba}$. This composition is also characteristic of hydrothermal sediment, but the enrichment of leachable element fractions suggests that this factor represents amorphous phases that have not been diagenetically altered to crystalline phases. The proportion of the sediment attributed to each factor for the two analyses is listed in Table 5 .

\section{Normative Partitioning}

It is clear from the multivariate statistical analysis of the basal sediment and from recent hydrothermal sediment analyses that most of the variance in the chemicals of these sediments can be explained by a few sediment components or factors. Furthermore, very similar factors control the variance in both data sets. The factors, however, appear to be mixtures of several phases.

It is therefore difficult to describe the relative importance of any particular source, say hydrothermal sources, in each sample. Thus normative partitioning of elements was employed in this study to extract information about the relative importance of sediment sources in metal-rich basal sediments. The partitioning model used is that developed by Dymond (in press). The model includes five sediment components: detritus, hydrothermal sediment, hydrogenous sediment, siliceous biogenic debris, and the residue of dissolved siliceous debris. The model assumes that the bulk sediment is influenced by contributions from only these five sources. The total concentration of each element is the sum of the concentrations from each of these sediment types:

$$
(X)_{t}=(X)_{d}+(X)_{h}+(X)_{a}+(X)_{b}+(X)_{s}+M
$$

where $(X)_{d}$ represents the detrital fraction of the element, $(X)_{a}$ the authigenic or hydrogenous fraction of the element, and so forth. $M$ is a residual that accounts for miscellaneous minor sources and analytical error and is small compared to the five major sources. In addition, the model assumes that the inter-element relationships or compositions of each of the five sedimentary source components are fixed within the spatial and temporal range being considered. This assumption seems justified by the multivariate statistical analysis. Because the interelement ratios of the components are fixed, the concentration of any element can be partitioned into contributions from each source. The partitioning of elements is carried out by solving a set of simultaneous linear equations by linear programming. 
Table 5. Proportion of sediment accounted for by factors generated from statistical analysis of bulk chemical composition and carbonate content of northeastern Pacific DSDP basal sediments.

\begin{tabular}{|c|c|c|c|c|}
\hline $\begin{array}{c}\text { Hole or } \\
\text { Site }\end{array}$ & $\begin{array}{c}\text { Factor 1 } \\
\text { "Hydrothermal" } \\
(\%)\end{array}$ & $\begin{array}{c}\text { Factor 2 } \\
\text { "Biogenic" } \\
(\%)\end{array}$ & $\begin{array}{c}\text { Factor 3 } \\
\text { "Detrital" } \\
(\%)\end{array}$ & $\begin{array}{c}\text { Factor } 4 \\
\text { "Carbonate" } \\
(\%)\end{array}$ \\
\hline 32 & 13 & 48 & 39 & 0 \\
\hline 36 & 1 & 46 & 53 & 0 \\
\hline 37 & 41 & 56 & 3 & 0 \\
\hline 38 & 9 & 0 & 0 & 91 \\
\hline $\begin{array}{l}39 \\
469\end{array}$ & 86 & 0 & 11 & 3 \\
\hline a & 6 & 90 & 4 & 0 \\
\hline b & 0 & 76 & 2 & 22 \\
\hline $\begin{array}{l}470 \mathrm{~A} \\
471\end{array}$ & 11 & 62 & 27 & 0 \\
\hline a & 5 & 90 & 5 & 0 \\
\hline b Reda & 4 & 92 & 4 & 0 \\
\hline b Green ${ }^{a}$ & 5 & 88 & 7 & 0 \\
\hline $\begin{array}{l}c \\
472\end{array}$ & 10 & 77 & 13 & 0 \\
\hline a & 0 & 61 & 39 & 0 \\
\hline b & 15 & 0 & 36 & 49 \\
\hline c & 0 & 6 & 5 & 89 \\
\hline
\end{tabular}

Note: Lower-case letters under specific holes indicate different samples or sections from these holes. Table 1 identifies these samples.

a Sample $47 \mathrm{I}_{\mathrm{b}}$ contains both grayish green and reddish brown sediment; the two sediment types were separated and analyzed individually.

The details of the technique are discussed by Geary and McCarthy (1964), Heath and Pisias (1979), and Dymond (in press).

The initial elemental ratios used in this study (see Table 6) were determined on the basis of literature values for components of surface sediments from the East Pacific Rise and Nazca Plate (Dymond, in press). Dymond (in press) did not include $\mathrm{Mg}$ and $\mathrm{Co}$ in his model, so it was necessary to determine component ratios for these elements. The hydrothermal components ratios for $\mathrm{Co}$ and $\mathrm{Mg}$ were chosen on the basis of their minimum ratio to $\mathrm{Fe}$ in modern metalliferous ridge-crest sediments (Böstrom, 1973; Dymond et al., 1976; Cronan, 1976). Authigenic component ratios for $\mathrm{Co}$ and $\mathrm{Mg}$ were chosen on the basis of their concentration in micro-laminated $\mathrm{Fe}$ and $\mathrm{Mn}$ micronodules (Eklund and Dymond, 1978) and ferromanganese crusts (Lyle, 1979). Biogenic ratios were chosen on the basis of the concentrations measured in siliceous biogenic material (M. Kastner, written communication, 1979).

Partioning of basal metalliferous sediments from the northeastern Pacific DSDP sites using the component ratios from Dymond's (in press) analysis of Nazca Plate sediment was only partially successful. The Dymond model ratios resulted in large negative residuals for several elements. The quantity $\left[(X)_{t}-(X)_{d}\right]$ was negative for $\mathrm{Si}, \mathrm{Mn}$, and $\mathrm{Fe}$, indicating that the ratios of these elements to detrital aluminum in the model were too large. The sources of terrigenous detritus for deepsea sediments in the subtropical northern Pacific are Central and North America. These source regions provide detritus that is less mafic than that contributed from South America. The quantity $\left[(X)_{t}-(X)_{d}-\right.$ $\left.(X)_{h}\right]$ was generally negative for $\mathrm{Cu}$ and $\mathrm{Zn}$, indicating
Table 6. Component compositions used to partition DSDP basal sediments.

\begin{tabular}{ccccccc}
\hline Element & Detrital & Hydrothermal & Biogenic & Authigenic & Solution Residue & Nazca Detritus \\
\hline $\mathrm{Mg}$ & 0.200000 & 0.060000 & 0.060000 & 5.400000 & 0.100000 & \\
$\mathrm{Al}$ & 1.000000 & 0.006000 & 0.002000 & 1.400000 & 0.500000 & 1.000000 \\
$\mathrm{Si}$ & 2.600000 & 0.130000 & 1.000000 & 3.700000 & 0.000000 & 3.000000 \\
$\mathrm{Mn}$ & 0.016000 & 0.290000 & 0.000023 & 30.000000 & 0.007000 & 0.160000 \\
$\mathrm{Fe}$ & 0.600000 & 1.000000 & 0.001000 & 14.000000 & 0.350000 & 0.750000 \\
$\mathrm{Co}$ & 0.000330 & 0.000027 & 0.000002 & 1.000000 & 0.000800 & 0.001500 \\
$\mathrm{Ni}$ & 0.001500 & 0.000900 & 0.000040 & 0.930000 & 0.006500 & 0.001200 \\
$\mathrm{Cu}$ & 0.000700 & 0.004200 & 0.000050 & 0.460000 & 0.160000 & 0.001400 \\
$\mathrm{Zn}$ & 0.001500 & 0.001900 & 0.000080 & 0.093000 & 0.004000 & 0.012000 \\
$\mathrm{Ba}$ & 0.010000 & 0.005000 & 0.002000 & 0.186000 & 1.000000 & \\
Note: All compositions are given as ratios: elements in the detrital component are listed as a ratio to Al; \\
for the hydrothermal component, elements are ratioed to Fe; for the authigenic component, elements \\
are ratioed to Co; for the biogenic component, elements are ratioed to Si; for the solution residue \\
component, elements are ratioed to Ba. in \\
a Detrital component ratios from Dymond (in press).
\end{tabular}

that either the detrital or hydrothermal component ratios for these elements were also too large. When the detrital component ratios were modified to a less mafic composition, the nondetrital component ratios required little modification. The ratios used are listed in Table 6 and the partitioning results for the data set are listed in Table 7.

The only elements that were not always well explained by the partitioning model were $\mathrm{Mn}$ and $\mathrm{Cu}$, two of the elements most mobile under the effects of reducing diagenesis. In the Leg 63 samples, which were from sediment intervals with evidence of reducing conditions (gray green sediment, $\mathrm{Mn}$ and $\mathrm{Fe}$ stains, reduction aureoles around pyrite), more $\mathrm{Mn}$ was required for the model than was present in the sediment. Thus there were large negative residuals for $\mathrm{Mn}$. The sediments that did have large $\mathrm{Mn}$ residuals also had large, negative $\mathrm{Cu}$ residuals. All of the other trace elements were fit to within $5 \%$ of their measured value. This quantity is greater than the analytical accuracy for the elements by atomic absorption analysis.

Partitioning of the northeastern DSDP sites indicates that the hydrothermal component makes up $15 \%$ to $97 \%$ (average $=40 \%$ ) of the noncalcareous sediment. Much of the variation in the importance of this component is probably the result of dilution by terrigenous and siliceous biogenic sediment rather than differences in the rate of accumulation of hydrothermal sediments. Many individual elements are dominantly hydrothermal

Table 7. Percentage of end-member components in basal DSDP sediments.

\begin{tabular}{llcccccc}
\hline Hole & Sample & Hydrothermal & Detrital & Biogenic & Authigenic & Solution & Residual \\
\hline 32 & & 30 & 36 & 30 & 0 & 4 & 0.50 \\
36 & & 11 & 45 & 39 & 0 & 5 & 1.23 \\
37 & & 67 & 14 & 19 & 0 & 0 & 1.26 \\
38 & & 98 & 1 & -0 & 1 & 0 & 0.32 \\
39 & & 98 & 2 & 0 & 0 & 0 & 1.91 \\
469 & a & 35 & 10 & 55 & 0 & 0 & 1.14 \\
& b & 16 & 6 & 79 & 0 & 0 & 1.16 \\
$470 \mathrm{~A}$ & & 18 & 17 & 62 & 0 & 3 & 0.46 \\
471 & a & 60 & 40 & 0 & 0 & 0 & 3.80 \\
& b green & 30 & 14 & 56 & 0 & 0 & 2.23 \\
& b red & 21 & 15 & 64 & 0 & 0 & 2.29 \\
472 & c & 16 & 10 & 74 & 0 & 0 & 1.44 \\
& a & 18 & 76 & 0 & 0 & 6 & 1.26 \\
& b & 40 & 22 & 34 & 0 & 4 & 1.08 \\
& c & 23 & 21 & 55 & 0 & 1 & 1.41 \\
\hline
\end{tabular}

Note: Residual is percentage of total composition unexplaned by partitioning model. Lower-case letters in Sample column indicate different samples identified in Table 1. Sample $47 \mathrm{I}_{\mathrm{b}}$ contains both grayish green and reddish brown sediment; the two sediment types were separated and analyzed individually. 
in origin. For example, only two samples (from Sites 36 and $471_{c}$ ) contain less than $50 \%$ hydrothermal iron, and the average basal sediment from these sites contains $70 \%$ hydrothermal iron.

The success of the normative partitioning model in explaining the bulk sediment composition points to two important conclusions. First, simple sedimentary components with uniform compositions are adequate to describe most of the variability in deep-sea sediments deposited within a single sedimentary province. And second, the composition of these sedimentary components within the northeast Pacific basin has not changed much in the last $50 \mathrm{~m} . \mathrm{y}$. It is not surprising that the composition of hydrogenous sediment, which is essentially chemical in nature, has not changed significantly. The composition of this sediment is probably controlled by mineralogy (Lyle, 1979). It is also understandable that within a specific ocean region the composition of detrital source material, if it changes at all, changes so slowly that it appears constant over a time span of 50 m.y. Because the trace-element content of biogenic debris is very small compared to the amount of these elements in other sediment components (see the ratios in Table 5), the model is largely insensitive to changes in the amount of elements in biogenic debris. In light of the variability observed in the composition of hydrothermal solutions from individual hydrothermal vents (Edmond et al., 1977; Edmond and Gordon, 1979; Corliss et al., 1979) and the variability predicted models of hydrothermal alteration (Seyfried and Bischoff, 1977; Mottl and Holland, 1978), it is surprising that the composition of hydrothermal sediment has not changed appreciably through time. It could be argued that the hydrothermal component ratios used to partition the hydrothermal concentrations are controlled by mineralogy and thus insensitive to changes in hydrothermal solution composition.

A comparison of the results of the factor analysis and of normative partitioning show that the two techniques give similar results. Samples that were enriched in the hydrothermal factors (Factor 1 in both the analysis of eight elements and the analysis of all of the chemical data) also had the highest concentrations of the hydrothermal component. The correlation between hydrothermal factor loading and concentration of the hydrothermal component $(r=0.86)$ confirms that both techniques reflect the distribution of the hydrothermal sediment. The advantage of the partitioning model is that true end-members are used and true end-member proportions are calculated. Therefore the results may be used as concentrations in calculating accumulation rates or mass balances.

The leach chemistry data indicate that much of the hydrothermal sediment is still present in the form of amorphous oxides and oxyhydroxides. An average of $60 \%$ (range, 9-93\%) of the bulk sediment can be leached with the oxalic-acid treatment. Although few of the samples had oxalate-leachable compositions (Table 8) similar to those present in recent hydrothermal sediments (Heath and Dymond, 1977), the data indicate that there has been little change in the overall composi-
Table 8. Ratios of elements to iron in the oxalate leachable sediment fraction.

\begin{tabular}{lccccccc}
\hline $\begin{array}{c}\text { Hole or } \\
\text { Site }\end{array}$ & $\mathrm{Al} / \mathrm{Fe}$ & $\mathrm{Si} / \mathrm{Fe}$ & $\mathrm{Mn} / \mathrm{Fe}$ & $\mathrm{Co} / \mathrm{Fe}$ & $\mathrm{Ni} / \mathrm{Fe}$ & $\mathrm{Cu} / \mathrm{Fe}$ & $\mathrm{Ba} / \mathrm{Fe}$ \\
\hline 32 & 0.152 & 0.214 & 1.328 & 0.019 & 0.010 & 0.010 & 0.007 \\
36 & 0.989 & 0.604 & 0.385 & 0.040 & 0.011 & 0.024 & 0.063 \\
469 & & & & & & & \\
a & 0.008 & 0.126 & 0.050 & 0.002 & 0.002 & 0.003 & 0.014 \\
$470 \mathrm{~A}$ & 0.288 & 0.034 & 0.208 & 0.023 & 0.004 & 0.016 & 0.151 \\
471 & & & & & & & \\
$\mathrm{a}$ & 0.257 & 0.308 & 0.039 & 0.013 & 0.001 & 0.001 & 0.014 \\
472 & & & & & & & \\
a & 0.031 & 0.082 & 1.772 & 0.005 & 0.008 & 0.008 & 0.033 \\
c & 0.233 & 0.349 & 0.281 & 0.021 & 0.007 & 0.008 & 0.151 \\
EPR & 0.006 & 0.100 & 0.290 & & 0.0014 & 0.0047 & 0.008 \\
\hline
\end{tabular}

Note: Row labeled "EPR" contains element/iron ratios for East Pacific Rise hydrothermal sediment from Heath and Dymond (1977). Lowercase letters under hole numbers indicate different samples identified in Table 1.

tion of the sediment. Consider, for example, the basal sediments from Site 38 . About $98 \%$ of the carbonatefree basal sediment from this site was partitioned into the hydrothermal component by the partitioning model. The carbonate-free bulk concentrations of the elements in this sample should therefore be good representatives of hydrothermal sediment composition. The ratios of transition elements to $\mathrm{Fe}$ in the bulk sediment are very close to the Dymond (in press) model hydrothermal ratios (Table 5). Fifty-two percent of the carbonate-free sediment from Site 319 basal sediments can be dissolved with buffered oxalic acid. The ratios of transition elements to $\mathrm{Fe}$ in the oxalate-leachabale sediment fraction are larger than the hydrothermal ratios used in the partitioning models, especially the $\mathrm{Mn} / \mathrm{Fe}$ ratio. Because the acetic acid leached less than $1 \mathrm{ppm} \mathrm{Fe}$, the difference in ratios cannot be explained by loss of $\mathrm{Fe}$ in the pretreatment of the samples. The increase in element to $\mathrm{Fe}$ ratios in the oxalate-leachable sediment fraction is consistent with diagenetic alteration of hydrothermal sediment to smectite as proposed by Heath and Dymond (1977), Eklund and Dymond (1978), and Bischoff et al. (1979).

Thus the results of this study indicate that much of the hydrothermal sediment deposited along the eastern Pacific spreading center during the Cenozoic persists as amorphous phases long after burial. In addition, the results confirm that as the sediment undergoes diagenesis, $\mathrm{Fe}$ is preferentially removed from leachable phases. The ratios of elements to $\mathrm{Fe}$ in the bulk sediment of samples with large hydrothermal contents are close to those of fresh hydrothermal sediment even though the oxalic-acid leachable fraction no longer has these ratios (see Table 8).

Finally, although the bulk composition of basal sediments recovered on Leg 63 are substantially different from those of basal sediments recovered on Leg 5 , the composition of end members such as detritus and hydrothermal sediment in samples from the two legs are very similar. The differences between the two sets of basal sediments can be attributed largely to differences in the amount of siliceous biogenic and detrital material in the sediment. 


\section{ACKNOWLEDGMENTS}

I am grateful to J. Dymond, G. R. Heath, and M. Lyle for continuing discussions of the origins of hydrothermal sediment and to N. G. Pisias for his assistance with and expertise in statistical methods for geochemical partitioning. G. R. Heath provided a thoughtful review of the manuscript. Cynthia Page performed analyses of the acetic-acid leach solutions. Special thanks are also due to the Glomar Challenger drilling crew for their extra care in recovering these thin sedimentary units immediately above and between basement rocks.

\section{REFERENCES}

Atwater, T., 1970. Implications of plate tectonics for the Cenozoic tectonic evolution of western North America. Bull. Geol. Soc. Am., 81:3513-3536.

Bernas, B., 1968. A new method for decomposition and comprehensive analysis of silicates by atomic absorption spectrometry. Anal. Chem., 40:1682-1686.

Bischoff, J. L., Heath, G. R., and Leinen, M., 1979. Geochemistry of deep-sea sediments from the Pacific manganese nodule province: DOMES Sites A, B, and C. In Bischoff, J. L, and Piper, D. Z. (Eds.), Marine Geology and Oceanography of the Central Pacific Manganese Nodule Province: New York (Plenum Press), pp. 397-436.

Boström, K., 1974. The origin and fate of ferromanganoan active ridge sediments. Stockholm Contrib. Geol., 27:149-243.

Boström, K., Kraemer, T., and Gartner, S., 1973. Provenance and accumulation rates of biogenic silica, $\mathrm{Al}, \mathrm{Ti}, \mathrm{Fe}, \mathrm{Mn}, \mathrm{Cu}, \mathrm{Ni}$, and Co in Pacific pelagic sediments. Chem. Geol., 11:123-148.

Boström, K., and Peterson, M. N. A., 1969. The origin of aluminumpoor ferromanganoan sediments in areas of high heat flow on the East Pacific Rise. Mar. Geol., 1:427-447.

Boyle, E. A., 1979. Cu, Ni, and Cd in the tests of Foraminifera. EOS, Trans. Am. Geophys. Union, 60:297. (Abstract)

Chester, R., and Hughes, M. J., 1967. A chemical technique for the separation of ferro-manganese minerals, carbonate minerals and adsorbed trace elements from pelagic sediments. Chem. Geol., 2:249-262.

Corliss, J. B., Dymond, J., Gordon, L. I., et al., 1979. Submarine hydrothermal springs on the Galapagos Rift. Science, 203:10731083.

Corliss, J. B., Lyle, M., Dymond, J., et al., 1978. The chemistry of hydrothermal sediment mound deposits near the Galapagos Rift. Earth Planet. Sci. Lett., 40:12-18.

Cronan, D. S., 1973. Basal ferruginous sediments cored during Leg 16, Deep Sea Drilling Project. In van Andel, Tj. H., and Heath, G. R., et al., Init. Repts. DSDP, 16: Washington (U.S. Govt. Printing Office), 601-604.

1976. Basal metalliferous sediment from the eastern Pacific. Bull. Geol. Soc. Am., 87:928-934.

Dymond, J., in press. Geochemistry of Nazca Plate surface sediments. An evaluation of hydrothermal, biogenous, detrital and hydrogenous sources. In Kulm, L. D., et al., (Eds.) Geol. Soc. Am. Mem.

Dymond, J., Corliss, J. B., Heath, G. R., et al., 1973. Origin of metalliferous sediments from the Pacific Ocean. Bull. Geol. Soc. Am., 84:3355-3372.

Dymond, J., Corliss, J. B., and Stillinger, R., 1976. Chemical composition and metal accumulation rates of metalliferous sediments from Site 319, 320B, and 321. In Yeats, R. S., Hart, S. R., et al., Init. Repts. DSDP, 34: Washington (U.S. Govt. Printing Office), 575-588.

Edmund, J. M., and Gordon, L. I., 1979. Galapagos hot springs revisited. EOS Trans. Am. Geophys. Union, 60:281.
Edmund, J. M., Gordon, L. I., and Corliss, J. B., 1977. Chemistry of the hot springs on the Galapagos Ridge axis. EOS Trans. Am. Geophys. Union, 58:1176.

Eklund, W. A., and Dymond, J., 1978. A microprobe study of metalliferous sediment components. Earth Planet. Sci. Lett., 40:243251.

Geary, R. C., and McCarthy, M. D., 1964. Elements of Linear Programming, with Economic Applications: New York (Hafner).

Hammond, S. R., and Epp, D., 1978. Comparison between models for the Neogene tectonic history of the Pacific Basin: Evidence for relative motion between the mantle and spin axis. 1978 Annual Meeting Geol. Soc. Am. Abstracts with Programs, 10:415.

Heath, F. R., and Dymond, J., 1977. Genesis and transformation of metalliferous sediments from the East Pacific Rise, Bauer Deep, and Central Basin, Northwest Nazca Plate. Bull. Geol. Soc. Am., $88: 723-733$.

, in press. Metalliferous-sediment deposition in time and space: East Pacific Rise and Bauer Basin, Northern Nazca Plate. In Kulm, L. D. V. (Ed.), Geol. Soc. Am. Mem.

Heath, G. R., and Pisias, N. G., 1979. A method for the quantitative estimation of clay minerals in North Pacific deep-sea sediments. Clays Clay Miner., 27:175-184.

Imbrie, J., and van Andel, Tj. H., 1964. Vector analysis of heavy mineral data. Bull. Geol. Soc. Am., 75:1131-1156.

Landa, E. R., and Gast, R. G., 1973. Evaluation of crystallinity in hydrated ferric oxides. Clays Clay Miner., 21:121-130.

Leinen, M., and Stakes, D., 1979. Metal accumulation rates in the central equatorial Pacific during the Cenozoic. Bull. Geol. Soc. Am., 90:357-375.

Lyle, M., 1979. The formation and growth of ferromanganese oxides on the Nazca Plate [Ph.D. dissert.]. Oregon State University, Corvallis, Oregon.

Minster, J. B., Jordan, T. H., Molnar, P., et al., 1974. Numerical modeling of instantaneous plate tectonics. Geophys. J. R. Astron. Soc., 36:541-576.

Mottl, M. J., and Holland, H. D., 1978. Chemical exchange during hydrothermal alteration of basalt by seawater-I. Experimental results for major and minor components of seawater. Geochim. Cosmochim. Acta, 42:1103-1115.

Pisias, N. G., and Leinen, M., 1980. Geochemical partitioning of deep-sea sediments using an extended version of Q-mode factor analysis and linear programming. 1980 Annual Meeting Geol. Soc. Am. Abstracts with Programs 12:500.

Prince, R. A., 1978. Southward motion of the Hawaiian hotspot between 42 and 25 MYBP. 1978 Annual Meeting Geol. Soc. Am. Abstracts with Programs, 10:474.

Seyfried, W., and Bischoff, J. L., 1977. Hydrothermal transport of heavy metals by seawater: the role of seawater/basalt ratio. Earth Planet. Sci. Lett., 34:71-77.

Spiess, F. N., Macdonald, K. C., Atwater, T., et al., 1980. East Pacific Rise: hot springs and geophysical experiments. Science, 207: 1421-1432.

Suarez, G., Molnar, P., and Sclater, J. G., 1979. Pacific plate motion during the Tertiary from continental paleomagnetism and the distribution of pelagic sediments. EOS Trans. Am. Geophys. Union, 60:239. (Abstract)

van Andel, Tj. H., Heath, G. R., and Moore, T. C., Jr., 1975. Cenozoic history and paleoceanography of the central equatorial $\mathrm{Pa}$ cific. Geol. Soc. Am. Mem., 143:1-134.

von der Borch, C. C., and Rex, R. W., 1970. Amorphous iron oxide precipitates in sediments cored during Leg 5, Deep Sea Drilling Project. In McManus, D. A., Burns, R. E., et al., Init. Repts. DSDP, 5: Washington (U.S. Govt. Printing Office), 541-544. 